\begin{tabular}{c|l|l|l|l}
\hline Volume 1 & Issue 2 & August (2020) & DOI: 10.47540/ijsei.v1i2.22 & Page: $48-52$ \\
\hline
\end{tabular}

\title{
A Surge in Cyber-Crime during COVID-19
}

\author{
Muhammad Kashif ${ }^{1}$, Aziz-Ur-Rehman ${ }^{2}$, Muhammad Kashan Javed ${ }^{3}$, Digvijay Pandey ${ }^{4}$ \\ ${ }^{1,2}$ Institute of Business Administration, Shaheed Benazir Bhutto University, Pakistan \\ ${ }^{3}$ Institute of Molecular Biology and Biotechnology, Baha Uddin Zakariya University, Pakistan \\ ${ }^{4}$ Department of Technical Education, IET, India
}

Corresponding Author: Muhammad Kashan Javed; Email: kashanjaved01@gmail.com

\begin{tabular}{|c|c|}
\hline A R T I & E I N F O \\
\hline $\begin{array}{l}\text { Keyword } \\
\text { Internet. }\end{array}$ & \\
\hline Received & : 08 June 2020 \\
\hline Revised & : 18 June 2020 \\
\hline Accepted & : 08 August, 2020 \\
\hline
\end{tabular}

A R T I C LE IN F O

\section{A B S T R A C T}

The prime goal of this research is to investigate if the cyber-crime has risen during corona virus. People are using more internet and electronic devices in this pandemic time in the purpose of to perform their works those are possible through internet, as they are unable to go out due to corona virus. For collection of data, it has been generated a questionnaire comprising of six questions. In these restrictions' times, data cannot be gathered interacting with people physically so social media has been used for gathering data. The questionnaire was sent to people through social media 1088 people were approached and 400 out of them responded on the questionnaire. The data is presented in different charts for analysis. This research is significant in knowing if people are being attacked or their data is being stolen more than ever before during corona virus. The outcomes of this study show that people are literally suffering through a surge in cyber-crime and most of the people said their data have been stolen and they have also been attacked by hackers.

\section{INTRODUCTION}

Cyber-crime is any crime committed through electronic devices (e.g. Computer or Smartphones) using internet such crimes include stealing data, harassing, spreading misinformation, misleading people, hacking accounts details etc. (Javed \& Javaid, 2020). As the nationwide lockdown have been imposed around the globe due to corona virus and it has been barred businesses to run their operations besides, people are not being allowed going out of home (Javaid \& Javaid, 2020). So, in such a situation, people are using internet to perform their works which they can do online like attending classes online, online shopping, online transactions, inter-action with people over the internet, earning money online and other works. Since most of the people are switched to online world so they are providing more data to websites (Bukht \& Javed, 2020). So, keeping in view this thing, this research is being carried out to know if cyber-crimes have surged during corona virus (Javed, Bukht \& Javaid, 2020). This research will prove helpful in knowing either people are suffering though this calamity or not and it will prove significant in finding out people are abstaining from providing data to websites in order to secure themselves from encountering any unwanted situation (Wang, Horby, Hayden, \& Gao, 2020; Pandey et.al, 2020; Srithazith, DeyBabu , Pandey, 2020).

The major purpose of this research is to examine if the cyber-crime is surging due to corona virus, besides it is also emphasized in the study to know if the people are providing more data to websites these days during corona virus and have encountered any bad situation (E.g. data stolen or hacking).

\section{MATERIALS AND METHODS}

It is generated a questionnaire to collect data on the topic of corona virus causes a rise in cybercrime. The questionnaire contains six different questions. Nationwide lockdown does not allow the collection of data by directly face-to-face interaction (YItayew, Ayenew, Pandey, Pandey, 2019; Ayenew \& Pandey, 2020; Sritha Zith Dey Babu, Pandey, \& Sheik, 2020; Ayenew, et al., 2012) with public, that is why the questionnaire is 
circulated on social media through different channels (Facebook and WhatsApp). The 1088 persons were sent the questionnaire and 400 people out of them responded on it. The response rate for this research is $37 \%$ which is low/good as compared to other online survey. For knowing if the cybercrime has risen during corona virus, different kinds of charts are formed. And percentage analysis is applied to find out the results. The results of this examination are listed in the following Diagrams.

\section{RESULTS AND DISCUSSION}

The results of this examination are listed in the following Diagrams.

\section{Use smartphone or any other digital devices}

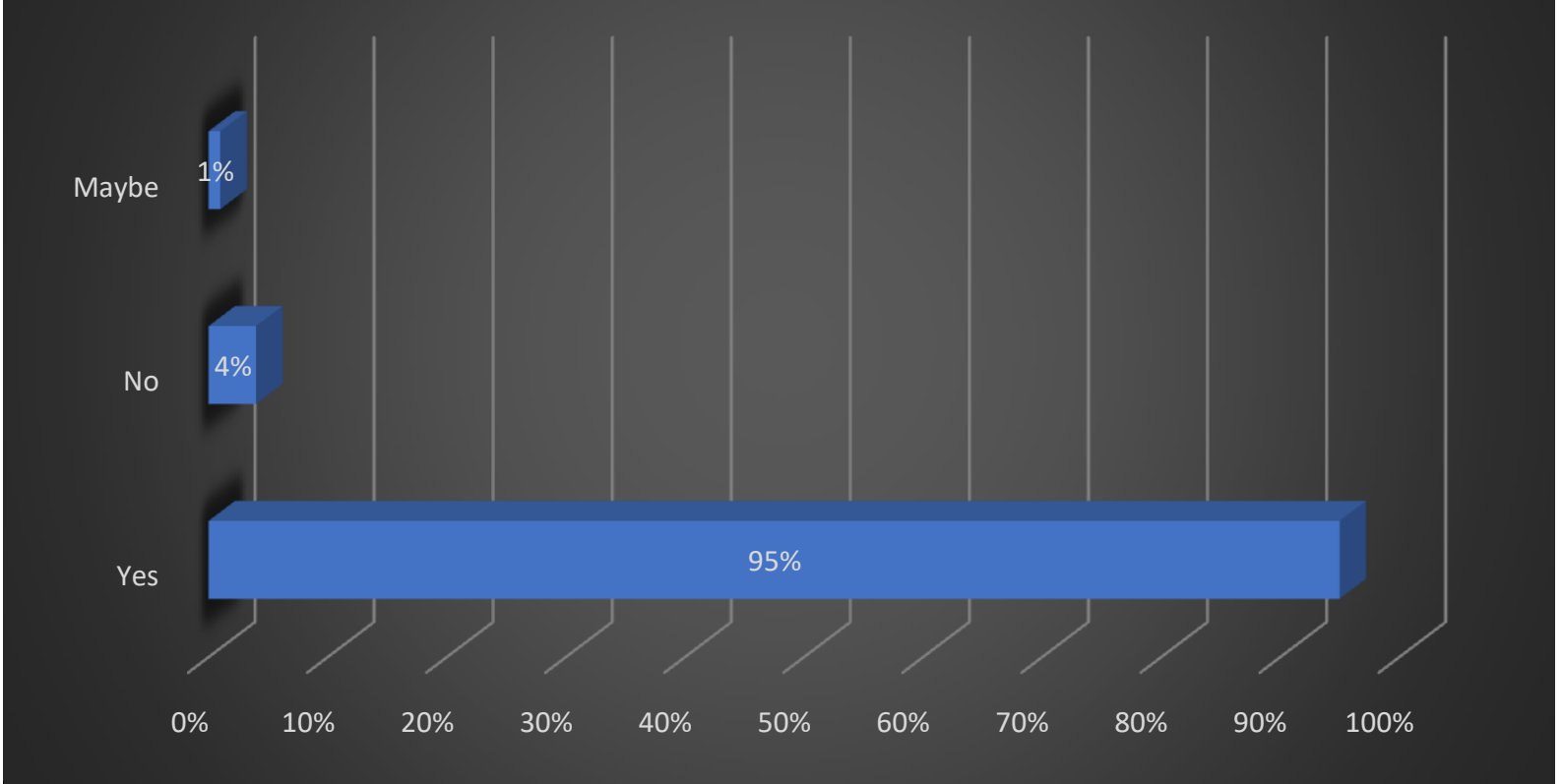

Figure 1: Use Smartphone or any Other Digital Devices

This chart shows that $95 \%$ people use people said that they do not use any device. $1 \%$ smartphones or other digital devices whereas $4 \%$ people were unsure about it.

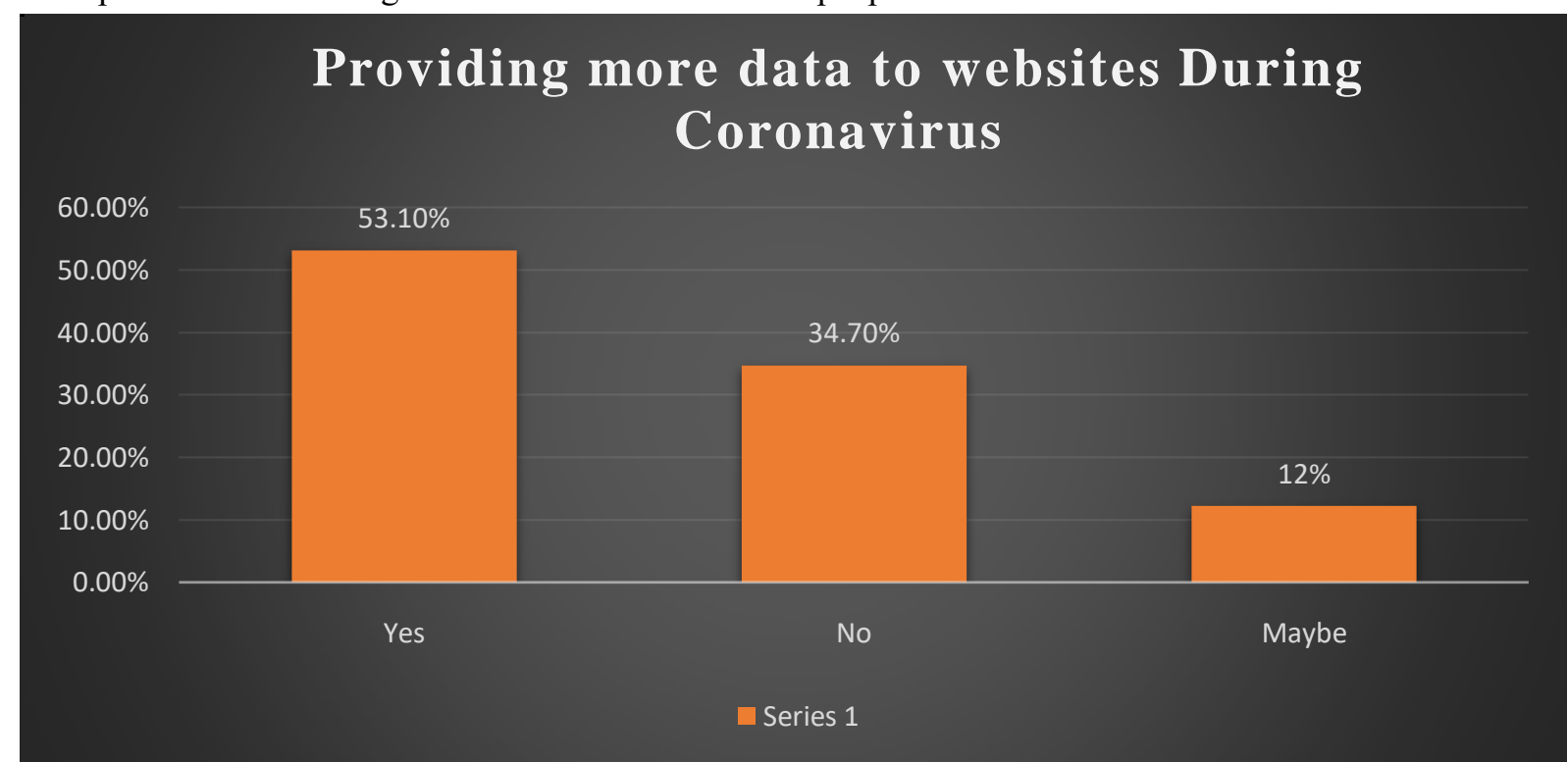

Figure 2: Providing more data to Websites during Corona Virus 
This figure shows that $53.10 \%$ people are agreed that it is being provided more data to websites During Corona virus while, $30.70 \%$ people said that it is not the case. $12 \%$ people are unsure about both the cases.

\section{Refrain providing data to online sites}

Yes

No

Maybe

Figure 3: Refrain Providing Data to Online Sites.

This graph shows that $48 \%$ people agreed that they refrain providing data to online sites during Covid-19 in order to protect it whereas, $35.70 \%$ people said that they do not abstain from providing data to websites. Rest of the people remained unsure about this case.

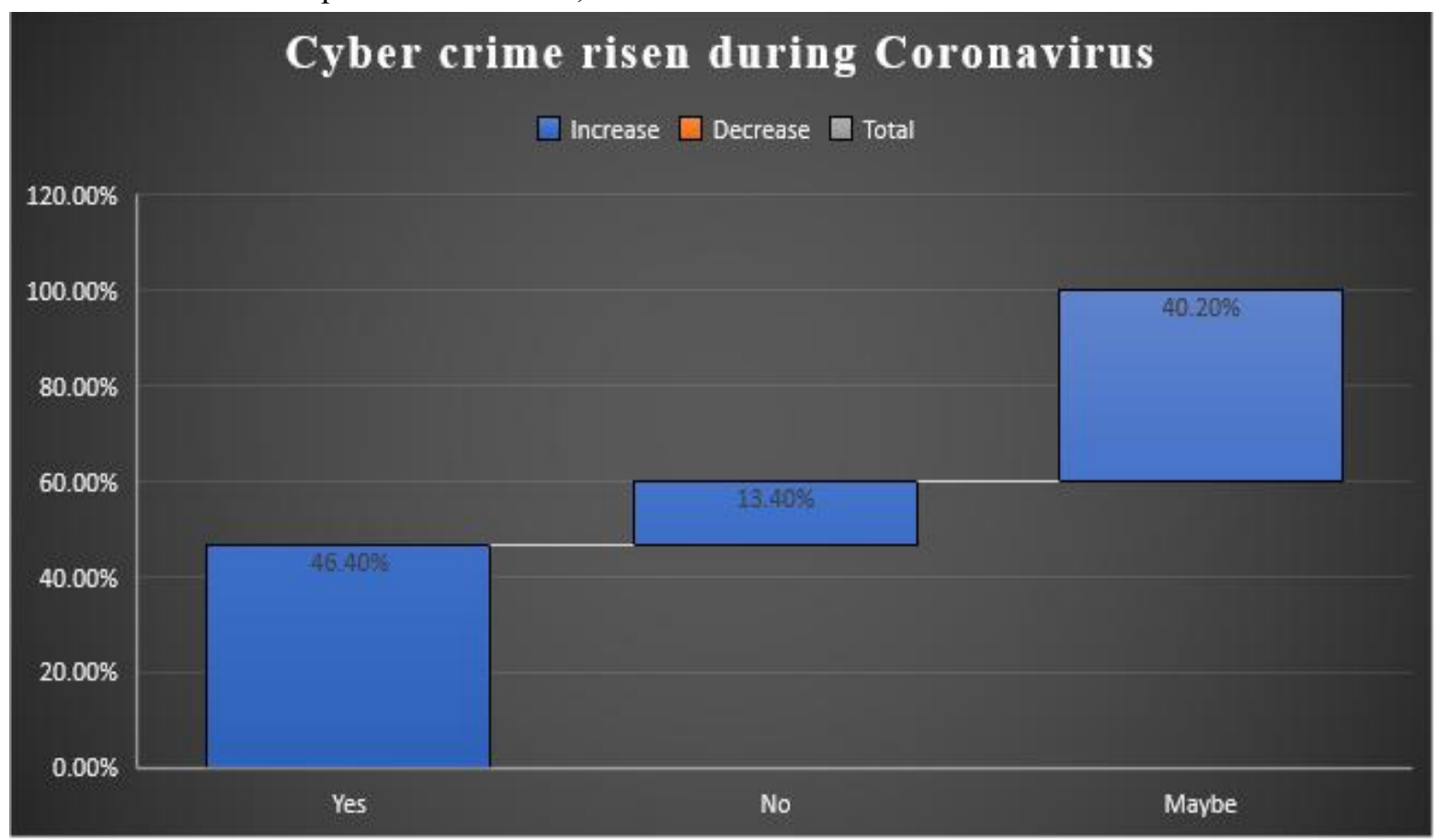

Figure 4: Cyber-Crime Risen During Corona Virus

From this picture it is known that almost $46.40 \%$ people agree that the cyber-crime has risen

while $13.40 \%$ people disagree on the statement. $40 \%$ people express uncertainty about it. 


\section{Attacked or data stolen during coronavirus}

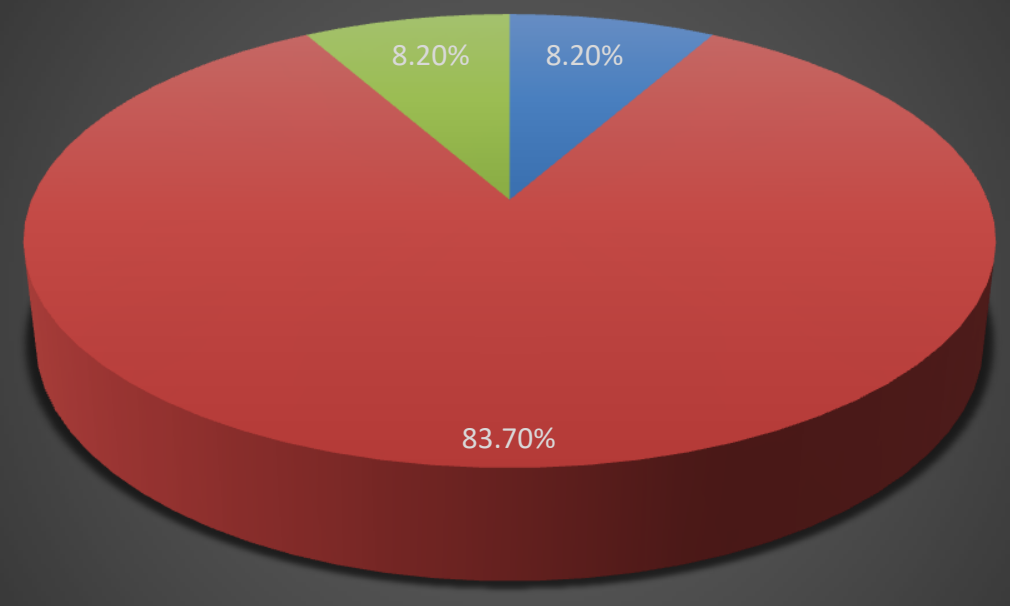

Yes No $\square$ Maybe

Figure 5: Attacked or Data Stolen During Corona Virus

This graph tells that almost $84 \%$ people said denied, and the same number of people expressed that they are being attacked or their data has been their unsurely.

stolen during corona virus whereas $8.20 \%$ people

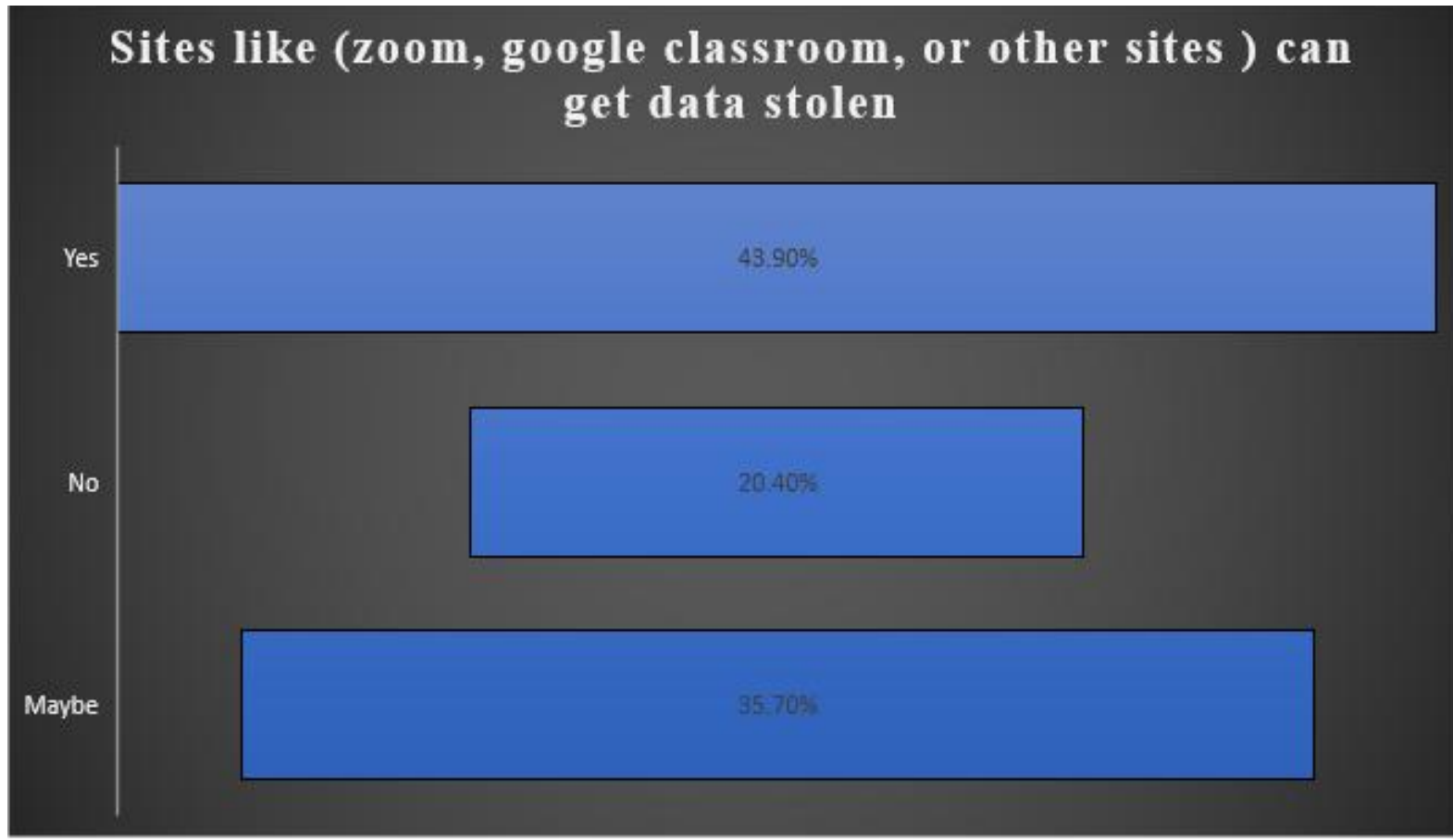

Figure 6: Sites Like (Zoom, Google Classroom, or Other Sites) Can Get Data Stolen

This figure shows that $43.90 \%$ people said that these sites can get their data stolen while, $20 \%$ people denied and other remained unsure. In future, A research should be carried out on the topic of methods and strategies to reduce cyber-crime during COVID-19.

\section{CONCLUSION}

Through this research, A conclusion has been drawn that there has come a rise in the cyber-crime during COVID-19, as most of the respondents agreed that they are facing a spike in data stealing and hackers attacks more these days. It has also 
been discovered that people abstain to provide their data any websites in a bid to secure it.

\section{REFERENCES}

Javed, M. K., \& Javaid, S. J. D. A. (2020). Corona Virus Awareness in Pakistan: A Case Study. International Journal of Medical Science in Clinical Research and Review, 3(03,), 256-262.

Javaid, S., \&Javaid, M. K. J. D. A. (2020). Survey on Corona Virus: A Case Study in Pakistan. International Journal of Medical Science in Clinical Research and Review, 3(02,), 223-227.

Bukht, N., \& Javed, M. K. (2020). Banker's Awareness of Corona Virus. Internatio-nal Journal of Medical Science in Clinical Research and Review, 3(03,), 251-255.

Javed, M. K., Bukht, N., \&Javaid, S. (2020). Covid19 Effect on Poor. Inter-national Journal of Medical Science in Clinical Research and Review, 3(03,), 263-268.

Wang, C., Horby, P. W., Hayden, F. G., \& Gao, G. F. (2020). A novel coronavirus outbreak of global health concern. The Lancet, 395(10223), 470-473.

Pandey, Digvijay et.al, "Infectivity, Preclusion, and Control (IPC) of Pandemic Novel COVID19", International Journal of Computer Engineering In Research Trends, 7(5): pp: 18, May 2020.

Srithazith, DeyBabu, Digvijay Pandey, "web-act of detecting covid 19", ijiert- International Journal of Innovations in Engineering Research and Technology, Volume 7, Issue 5, ISSN: 2394-3696, Page No. 21-30, 2020.

YItayew M, Ayenew B, Pandey D, Pandey B. Indigenous Conflict Resolution Systems and Practices: Implications for Social Relation Ship Developmen": The Case of Debre Markos Town, 2019. Alq J Med App Sci. ;3(1)53-60, 2020.

Ayenew B. and Digvijay Pandey "Challenges and opportunities to tackle COVID-19 spread in Ethiopia”. Journal of Peer Scientist. 2020;2(2):e1000014, 2020.

SrithaZithDeyBabu, Pandey, D., Sheik, I., "an overview of a crime detection system using the art of data mining", ijiert- International Journal of Innovations in Engineering
Research and Technology, Volume 7, Issue 5, ISSN : 2394-3696, Page No. 125-128, 2020.

Ayenew B, Pandey D, Yitayew M, Etana D, Binay Kumar P, Verma N, et al. Risk for Surge Maternal Mortality and Morbidity during the Ongoing Corona Virus Pandemic. Med Life Clin. 2020; 2(1): 1012. 